\title{
Enfermo con adjetivo
}

\section{SICK OF BEING CATEGORIZED}

En una edición anterior de esta revista encontré un título que, con el perdón del autor, me resultó llamativo para comenzar a garabatear esta página en blanco. "Demencia un tema urgente para Chile" escribió Jean Gajardo para referirse a ese síndrome clínico. Este "copia y pega" llega sólo hasta el titular. Mi teclado que ignora todo sobre medicina piensa que la demencia se apoderó hace varias décadas de esta sociedad. Los pobres saben que algo está mal pero, anestesiados por los bonos y subsidios, no identifican muy bien las causas y el típico "está mal pelado el chancho" es la más certera conclusión. Juicio más que comprensible en el caso de los que viven en la miseria y sólo tienen tiempo de rebuscárselas para sobrevivir. Sin embargo, al subir por la escala social, encontramos que un sector importante de la clase media también tiene dificultades para explicar el origen de su malestar crónico. Y a los que están más arriba, salvo excepciones, simplemente no les interesa reflexionar mucho sobre los cimientos de su posición. En mi opinión, mientras no se ataque el problema del salario en Chile con el pretexto de cuidar el sacrosanto crecimiento económico la mitad de los problemas de país no tiene solución.

Pero volvamos a este plato. Muchos han llegado al convencimiento que, una persona acomodada es privilegiada cuando recibe una atención médica de calidad. Prácticamente, un sinvergüenza que, a costa de vaya a saber quién, puede darse ese "lujo".

Cuando un paciente es etiquetado según los millones o chauchas que posee, es la pérdida absoluta de una mirada humanista.

Escabrosa reacción que se ha convertido en una peligrosa manía. Cuando se desemboca en esto, quiere decir que el modelo liberal, el original de derecha o ese de la centro tibia izquierda, nos condujeron a la demencia. 